\title{
Assessment of Serum Endocan and sICAM-1 Levels as Markers of Endothelial Dysfunction and Systemic Inflammation and Their Relationship with Comorbidities in COPD Patients
}

\author{
KOAH Hastalarında Endotel Disfonksiyonu ve Sistemik İnflamasyon \\ Belirteçleri Olarak Serum Endokan ve sICAM-1 Düzeylerinin \\ Değerlendirilmesi ve Bunların Komorbiditelerle Olan İlişkisi
}

\section{Onur YAZICI ${ }^{\oplus} \oplus$, Fisun KARADAĞ́ ${ }^{1} \oplus$, Şule TAŞ GÜLEN ${ }^{1} \oplus$, Burcu TALAY MUSTAFAOĞLU ${ }^{2} \oplus$, Aslıhan BüYüKÖZTüRK KARUL ${ }^{3 \oplus}$}

Cite as: Yazııı O, Karadağ F, Taş Gülen Ş, Talay Mustafaoğlu B, Büyüköztürk Karul A. Assessment of serum endocan and sICAM-1 levels as markers of endothelial dysfunction and systemic inflammation and their relationship with comorbidities in COPD patients. İzmir Göğüs Hastanesi Dergisi. 2021;35(1):1-10.

\begin{abstract}
Objective: Chronic obstructive pulmonary disease (COPD) has systemic effects and is accompanied by numerous comorbidities. Systemic inflammation and endothelial dysfunction increase the incidence of comorbidities in COPD. Endocan and Intercellular Adhesion Molecule-1 (ICAM-1) can be used as indicators for determining endothelial dysfunction and systemic inflammation. We aimed to investigate endothelial dysfunction and systemic inflammation using endocan and sICAM-1 levels and determine associations of these indicators with comorbidities in COPD patients.

Method: COPD patients who presented to Outpatient Chest Diseases Clinic between May 2018 and May 2019 and a control group were included in the study. Demographic data, comorbidities, forced vital capacity (FVC)\%, forced expiratory volume in 1-second (FEV1)\%, and FEV1/FVC, Modified Medical Research Council (mMRC) dyspnea scores, and COPDassessment-questionnaire (CAT) scores of COPD patients were recorded. COPD patients were divided into two groups as those with/without comorbidities. Besides, they were classified into four groups (A-D) according to the GOLD (Global Initiative for Obstructive Lung Disease) classification. Serum endocan and soluble ICAM-1 (sICAM-1) levels were measured by the ELISA method.

Results: Endocan and sICAM-1 levels of the COPD group were higher ( $<<0.001$ and $p=0.031$, respectively). COPD and Control Groups had similar incidences of comorbidities except for coronary artery disease. Serum endocan and sICAM-1 levels of COPD patients with/without comorbidities and COPD subgroups were similar. Endocan had negative correlations with $\mathrm{FVC} \%$ and $\mathrm{FEV} 1 \%$ and was positively correlated with CAT, mMRC, and smoking, whereas sICAM-1 was positively correlated with the amount of smoking.

Conclusion: Endothelial dysfunction and systemic inflammation are present independent of comorbidities and disease severity in COPD patients. Endocan and sICAM-1 can be used to indicate this condition. Endocan can be used, but sICAM-1 is insufficient to predict airway obstruction severity.
\end{abstract}

Keywords: chronic obstructive pulmonary disease, endocan, soluble intercellular adhesion molecule-1, endothelial dysfunction, systemic inflammation

öz

Amaç: Kronik obstrüktif akciğer hastalığı (KOAH) birçok komorbiditenin eşlik ettiği ve sistemik etkileri olan bir hastalıktır. Sistemik inflamasyon ve endotel disfonksiyonu KOAH'da komorbidite görülme sıklı̆̆ını arttırmaktadır. Endokan ve hücreler arası adezyon molekülü 1(ICAM-1) endotel disfonksiyonu ve sistemik inflamasyonu belirlemede belirteç olarak kullanılabilir. Biz de çalısmamızda, KOAH hastalarında endokan ve ICAM-1 düzeyi ile endotel disfonksiyonu ve sistemik inflamasyonu değerlendirmeyi ve komorbiditelerin bu belirteçlerle olan ilișkisini değerlendirmeyi amaçladık.

Yöntem: Calıșmamıza Mayıs 2018-Mayıs 2019 tarihleri arasında Göğüs Hastalıkları Polikliniğine başvuran KOAH hastaları ve kontrol grubu alındı. Tüm olguların demografik verileri, komorbiditeleri, zorlu vital kapasite (FVC) \%, zorlu ekspiratuvar volüm birinci saniye (FEV1) \% ve FEV1/FVC parametreleri ve Modified Medical Research Council (mMRC) dispne skalası skorları ile KOAH olgularının KOAH değerlendirme anketi (CAT) skorları kaydedildi. KOAH hastaları komorbiditesi olan ve olmayanlar olarak 2 gruba ayrıldı. KOAH hastaları ayrıca GOLD sınıflamasına göre A'dan D'ye 4 gruba ayrıldı. Endokan ve soluble ICAM-1 (sICAM-1) düzeyleri serumda ELISA yöntemiyle ölçüldü.

Bulgular: KOAH grubunda endokan ve sICAM-1 değerleri daha yüksekti ( $p$ değerleri sırasıyla $<0.001$ ve 0.031 ). KOAH ve kontrol grupları arasında koroner arter hastalığı dıșındaki komorbiditeler benzer sıkıktaydı. Komorbiditesi olan ve olmayan KOAH hastaları arasında ve KOAH grupları arasında serum endokan ve sICAM-1 düzeyleri benzerdi. Endokan, FVC\% ve FEV1\% ile negatif yönde, CAT, mMRC ve sigara kullanımı ile pozitif yönde korelasyon gösteriyorken, sICAM- 1 yalnızca sigara kullanım miktarılya pozitif korelasyon gösteriyordu.

Sonuç: KOAH hastalarında komorbiditelerden ve hastalık ağırlığından bağımsız olarak endotel disfonksiyonu ve sistemik inflamasyon vardır. Endokan ve sICAM-1 bu durumu göstermede kullanılabilir belirteçlerdir. Endokan hava yolu obstrüksiyonun ağırlığını öngörmede kullanılabilirken, sICAM 1 bunu öngörmede yetersizdir.

Anahtar kelimeler: karsinoid tümör, sleeve rezeksiyon, bronkoplastik rezeksiyon, VATS, robotik cerrahi
Received/Gelis: 26.01.2021

Accepted/Kabul: 12.03.2021

Published Online/Online Yayın: 29.04.2021

Corresponding author/Sorumlu yazar:

O. Yazıcı

ORCID: 0000-0002-6272-4632

Aydın Adnan Menderes Üniversitesi Tıp Fakültesi

Göğüs Hastalıkları Anabilim Dalı Aydın - Türkiye

dronur_yazici@hotmail.com

F. Karadă

ORCID: 0000-0002-8961-7079

S. Tas Gülen

ORCID: 0000-0002-0517-2376

Aydın Adnan Menderes Üniversitesi

Tıp Fakültesi, Göğüs Hastalıkları Anabilim Dalı Aydın, Türkiye

B. Talay Mustafaoğlu

ORCID: 0000-0001-9920-0659

Isparta Sehir Hastanesi, Göğüs Hastalıkları Kliniği,

Isparta, Türkiye

A. Büyüköztürk Karul

ORCID: 0000-0002-3738-2888

Aydın Adnan Menderes Üniversitesi Tıp Fakültesi, Tıbbi Biyokimya Anabilim Dalı, Aydın, Türkiye

() Telif hakkı İzmir Göğüs Hastanesi'ne aittir. Logos Tıp Yayıncllık tarafından yayınlanmaktadır.

Bu dergide yayınlanan bütün makaleler Creative Commons 4.0 Uluslararası Lisansı (CC BY) ile lisanslanmıștır. 


\section{INTRODUCTION}

Chronic obstructive pulmonary disease (COPD) is a heterogeneous disorder with systemic effects, characterized by permanent airway obstruction, and accompanied by numerous comorbidities ${ }^{(1,2)}$. Airway and parenchymal alterations and various degrees of endothelial injury and microvascular inflammation are among characteristic changes in COPD ${ }^{(3,4)}$. Endothelial dysfunction and systemic inflammation increase the incidence of comorbidities, causing increased morbidity and mortality rates in COPD patients ${ }^{(5,6)}$. For this reason, determining the indicators of systemic inflammation and endothelial dysfunction would provide meaningful information regarding disease prognosis in COPD patients.

Endocan is a proteoglycan mainly expressed by pulmonary and renal endothelial cells ${ }^{(3)}$. It is expressed by endothelial cells activated in the presence of inflammation and prevents leukocytes' binding to vascular endothelium by interacting with adhesion molecules ${ }^{(7)}$. The number of studies conducted with endocan in the respiratory system is limited. There are studies related to acute pulmonary injury, acute respiratory distress syndrome, lung cancer, community-acquired pneumonia, pulmonary embolism, and obstructive sleep apnea syndrome ${ }^{(3,8-12)}$. There are few studies related to the endocan level in COPD patients, and their results are contradictory ${ }^{(13-15)}$.

Intercellular adhesion molecule-1 (ICAM 1) is one of the adhesion molecules with which leukocytes bind to endothelial cells. Under physiological circumstances, ICAM-1 is secreted in exceedingly small amounts by endothelial cells, epithelial cells, lymphocytes, neutrophils, and monocytes ${ }^{(16)}$. However, when inflammation is present, it is expressed primarily by endothelial cells and participates in leukocytes' adhesion ${ }^{(17,18)}$. Soluble ICAM-1 (sICAM-1) has been investigated in studies related to acute pulmonary injury, asthma, lung cancer, and pulmonary fibrosis (16,19-21). Few studies have evaluated SICAM-1 in COPD ${ }^{(22-24)}$. It has been stated that both endocan and SICAM-1 could be used as biological indicators for showing endothelial dysfunction and systemic inflammation ${ }^{(3-18)}$.

Our study aimed to evaluate endothelial dysfunction and systemic inflammation using endocan and sICAM-1 levels and determine associations of these indicators with comorbidities in COPD patients.

\section{MATERIALS and METHODS}

The study was initiated following the approval of the Adnan Menderes University Ethical Committee (Protocol no: 2018/1387). The study conducted in accordance with the principles of the Declaration of Helsinki. Detailed information about the study was provided to all participants, and then they signed the informed consent form. Patients who presented to the Outpatient Clinic of Department of Chest Diseases in Aydın Adnan Menderes University between May 2018 and May 2019, having a diagnosis of COPD for at least one year and were stable for the last three months were included in the study. The control group involved cases with no known respiratory disorder and similar age and gender to the study group. Patients under 40 years of age, those with a medical history of malignancy, those who had encountered an acute coronary syndrome or acute cerebrovascular disorder within the last three months, and those who had symptoms and signs of acute infection at the time of admission were excluded from the study.

\section{Study protocol}

Age, gender, body mass index (BMI), smoking status, and comorbidity history were recorded in all cases. Pulmonary function test was performed following the American Thoracic Surgery / European Respiratory Society criteria in all cases, and the parameters of forced vital capacity (FVC) 
$\%$, forced expiratory volume 1 st second (FEV1) \%, and FEV1/FVC were recorded (25). The COPD assessment questionnaire (CAT) was applied and recorded in all COPD cases. The modified Medical Research Council (mMRC) dyspnea scale scores of all cases were recorded. COPD patients were classified into four groups as A, B, C, and D according to the symptoms and exacerbation frequency specified in the Global Initiative for Chronic Obstructive Lung Disease (GOLD) 2017 criteria ${ }^{(1)}$.

\section{Measurement of endocan and ICAM-1}

The samples obtained from the patients were centrifuged and kept at $-80^{\circ} \mathrm{C}$ until the analysis day. In this study, endocan and SICAM-1 were measured by the ELISA method (FineTest, Wuhan Fine Biotech Co., Ltd.; China; Catalog \# EH0161 and EH0125). The endocan and SICAM-1 ELISA kits involve 96-well plates, and each of these wells is coated with endocan and SICAM-1 antibodies. The endocan and SICAM-1 antibodies conjugated with biotin are used as the detection antibodies. Standards, samples, and biotin-conjugated detection antibodies are initially added to the plate, and the plate is washed following incubation. Conjugates that are unable to provide binding are removed by washing. Then, adherence to detection antibodies is enabled by adding HRP-Streptavidin (horseradish peroxidase-Streptavidin). TMB (tetramethylbenzidine) substrate is added to the medium as a colorforming substance to observe the enzymatic reaction of HRP. Lastly, an acidic stop solution is added to the wells to convert blue color occurring after TMB addition to yellow. The optical density of the occurring yellow color is read at $450 \mathrm{~nm}$ using a microplate reader, and endocan and sICAM-1 values are calculated according to the standard graph obtained. The results were presented in $\mathrm{pg} / \mathrm{ml}$ for endocan and $\mathrm{ng} / \mathrm{ml}$ for sICAM-1.

\section{Statistical Analysis}

The data were analyzed using the SPSS software (IBM SPSS Statistics for Windows, Version 23.0. Armonk, NY, USA). The conformity of the variables with a normal distribution was determined using the Kolmogorov - Smirnov test. The continuous variables with a normal distribution were expressed as mean \pm standard deviation, and those without a normal distribution were expressed as median (25-75 percentile). Categorical variables were expressed as numbers and percentages. Student t-test, and when more than two independent variables were present, ANOVA were used for continuous variables showing a normal distribution. Mann-Whitney U test, and when more than two independent variables were present, the Kruskal Wallis test were used for continuous variables not showing a normal distribution. Pearson's chi-square test and Fisher exact test were used for the analysis of categorical variables. Pearson correlation analysis was used to analyze the relationships between the variables. The value of $\mathrm{p}<0.05$ was considered statistically significant.

\section{RESULTS}

A total of 87 COPD cases with a mean age of $68.56 \pm 6.94$ years, 85 of whom male, and a total of 70 control cases with a mean age of $66,67 \pm 6,68$ years, all of whom male, were included in the study. The two groups were similar regarding age and gender $(p=0.087$ and $p=0.168$, respectively). The BMI of the COPD group was statistically significantly lower than the control group $(p=0.001)$. The frequency of smoking and the COPD group's mMRC score were significantly higher than the control group $(p<0.001$ and $p<0.001$, respectively). While comorbidity was present in $56.3 \%$ of the COPD cases, $42.9 \%$ of the control cases had comorbidity $(p=0.093)$. The most common comorbidity was hypertension in the COPD and control groups. All comorbidities 
Table 1. Demographic, functional, and laboratory parameters of the COPD and control groups.

\begin{tabular}{|c|c|c|c|}
\hline Variables & $\begin{array}{r}\text { COPD } \\
(n=87)\end{array}$ & $\begin{array}{c}\text { Control } \\
(n=70)\end{array}$ & $\mathbf{p}$ \\
\hline Age (years) & $68.56 \pm 6.94$ & $66.67 \pm 6.68$ & 0.087 \\
\hline \multicolumn{4}{|l|}{ Gender } \\
\hline Female (n, \%) & $0(0)$ & $3(3.5)$ & 0.168 \\
\hline Male (n, \%) & $87(100)$ & $84(96.5)$ & \\
\hline BMI & $25.95 \pm 4.11$ & $28.03 \pm 3.41$ & 0.001 \\
\hline \multicolumn{4}{|l|}{ Comorbidity } \\
\hline Present & $49(56.3)$ & $30(42.9)$ & 0.093 \\
\hline Absent & $38(43.7)$ & $40(57.1)$ & \\
\hline \multicolumn{4}{|l|}{ Smoking history (n, \%) } \\
\hline Nonsmoker & $0(0)$ & $34(48.6)$ & $<0.001$ \\
\hline Ex-smoker & $59(67.8)$ & $18(25.7)$ & \\
\hline Active smoker & $28(32.2)$ & $18(25.7)$ & \\
\hline Amount of smoking (packs/year) & $50(40-68)$ & $7(0-30)$ & $<0.001$ \\
\hline CAT & $11.16 \pm 7.61$ & & \\
\hline $\mathrm{mMRC}$ & $2(1-3)$ & $0(0-1)$ & $<0.001$ \\
\hline FVC (\% pred) & $81.16 \pm 21.48$ & $101.51 \pm 12.7$ & $<0.001$ \\
\hline FEV1 (\%) & $61.36 \pm 20.53$ & $100.89 \pm 13.88$ & $<0.001$ \\
\hline FEV1/FVC & $58.1(48.8-66.65)$ & $78.11(76.1-82.2)$ & $<0.001$ \\
\hline Endocan & $366.85 \pm 57.94$ & $311.34 \pm 44.12$ & $<0.001$ \\
\hline ICAM-1 & $57.37 \pm 15.05$ & $51.89 \pm 16.41$ & 0.031 \\
\hline
\end{tabular}

BMI: body mass index, CAT: COPD assessment test, mMRC: Modified Medical British Research Council dyspnea questionnaire, FVC: forced vital capacity, \% pred.: percent predicted, FEV1: forced expiratory volume in 1 s., ICAM-1: Intercellular Adhesion Molecule-1.

were similar in both groups except for coronary artery disease $(p>0.05)$. Coronary artery disease was significantly more common in the COPD group than the control group $(p=0.007)$. The FVC\%, FEV1\%, and FEV1/FVC values were significantly lower in the COPD group compared to the control group $(p<0.001, p<0.001$, and $p<0.001$, respectively).

The endocan and SICAM-1 levels were significantly higher in the COPD group than the control group $(p<0.001$ and $p=0.031$, respectively). Demographic characteristics and the values of functional and laboratory parameters were presented in Table 1, and comorbidities of all cases were given in Table 2. When the COPD cases were divided into two groups as with/without comorbidity, it was determined that the mean age was $71.83 \pm 5.18$ years in the patient group with comorbidity and $64.34 \pm 6.69$ years in the group with no comorbidity $(p<0.001)$. Both groups were similar regarding gender, BMI, pulmonary function test parameters, CAT, and mMRC scores ( $p>0.05)$. The ratio of active smokers was higher in the patient group without comorbidity than the group with comorbidity $(p=0.027)$. However, the amount of smoking was similar in both groups $(p=0.088)$. The serum endocan and sICAM-1 levels were similar in both groups 
O. Yazıcı ve ark., Endothelial Dysfunction and Systemic Inflammation in COPD

Table 2. Comorbidities in the COPD and control groups.

\begin{tabular}{lccc}
\hline Comorbidities $^{*}$ & $\begin{array}{c}\text { COPD } \\
(\mathbf{n = 8 7})\end{array}$ & $\begin{array}{c}\text { Control } \\
(\mathbf{n = 7 0 )}\end{array}$ \\
\hline Diabetes mellitus n (\%) & $15(17.24)$ & $14(20)$ & $\mathbf{p}$ \\
Hypertension & $27(31.03)$ & $23(32.86)$ & 0.658 \\
Coronary artery disease & $18(20.69)$ & $4(5.71)$ & 0.007 \\
Heart failure & $3(3.45)$ & $1(1.42)$ & 0.007 \\
Cardiac valve disease & $3(3.45)$ & $1(1.42)$ & 0.117 \\
Atrial fibrillation & $5(5.75)$ & $3(4.29)$ & 0.425 \\
Hyperlipidemia & $7(8.05)$ & $2(2.86)$ & 0.161 \\
Chronic renal failure & $2(2.3)$ & $3(4.29)$ & 0.338 \\
Gastroesophageal reflux & $2(2.3)$ & $3(4.29)$ & 0.825 \\
Hypothyroidism & $3(3.45)$ & $0(0)$ & 0.481 \\
Hyperthyroidism & $1(1.15)$ & $0(2.86)$ & 0.786 \\
Rheumatoid arthritis & $1(1.15)$ & $0(0)$ & 0.368 \\
Gut & $3(3.45)$ & $2(5.71)$ & 0.692 \\
Benign prostate hyperplasia & $9(10.35)$ & $4(5.71)$ & 0.117 \\
Alzheimer & $2(2.3)$ & & 0.295 \\
Anxiety disorder & $6(6.9)$ & 0.825 \\
\hline
\end{tabular}

* Some patients had more than one comorbidity

Table 3. Demographic, functional, and laboratory parameters of COPD patients with and without comorbidities.

\begin{tabular}{|c|c|c|c|}
\hline Variables & $\begin{array}{l}\text { With comorbidity } \\
\qquad(\mathrm{n}=49)\end{array}$ & $\begin{array}{l}\text { Without comorbidity } \\
\qquad(\mathrm{n}=\mathbf{3 8})\end{array}$ & $\mathbf{p}$ \\
\hline Age (years) & $71.83 \pm 5.18$ & $64.34 \pm 6.69$ & $<0.001$ \\
\hline \multicolumn{4}{|l|}{ Gender } \\
\hline Female (n, \%) & $2(4.1)$ & $1(2.6)$ & 0.595 \\
\hline Male (n, \%) & 47 (95.9) & $37(97.4)$ & \\
\hline BMI & $26.3 \pm 4.08$ & $25.51 \pm 4.17$ & 0.375 \\
\hline \multicolumn{4}{|l|}{ Smoking history (n, \%) } \\
\hline Nonsmoker & $0(0)$ & $0(0)$ & 0.027 \\
\hline Ex-smoker & $38(77.6)$ & $21(55.3)$ & \\
\hline Active smoker & $11(22.4)$ & $17(44.7)$ & \\
\hline Amount of smoking (packs/year) & $55(40-80)$ & $46.5(35-51.25)$ & 0.088 \\
\hline CAT & $10.51 \pm 6.94$ & $12 \pm 8.41$ & 0.368 \\
\hline $\mathrm{mMRC}$ & $2(1-2.5)$ & $2(1-3)$ & 0.879 \\
\hline FVC (\% pred) & $83.59 \pm 22.16$ & $78.08 \pm 20.46$ & 0.240 \\
\hline FEV1 (\%) & $64.09 \pm 19.83$ & $57.91 \pm 21.13$ & 0.167 \\
\hline FEV1/FVC & $59.65(50.01-66.6)$ & $57.8(47.5-67)$ & 0.399 \\
\hline Endocan & $366.01 \pm 52.51$ & $367.94 \pm 64.98$ & 0.878 \\
\hline ICAM 1 & $58.14 \pm 16.17$ & $56.37 \pm 13.64$ & 0.589 \\
\hline
\end{tabular}

BMI: body mass index, CAT: COPD assessment test, mMRC: Modified Medical British Research Council dyspnea questionnaire, FVC: forced vital capacity, \% pred.: percent predicted, FEV1: forced expiratory volume in 1 s., ICAM-1: Intercellular Adhesion Molecule-1. 
Table 4. Demographic, functional, and laboratory parameters of the COPD groups.

\begin{tabular}{|c|c|c|c|c|c|}
\hline Characteristics & $\begin{array}{c}\text { COPD group } A \\
(n=26)\end{array}$ & $\begin{array}{l}\text { COPD group B } \\
(\mathbf{n}=32)\end{array}$ & $\begin{array}{c}\text { COPD group } C \\
(n=10)\end{array}$ & $\begin{array}{l}\text { COPD group D } \\
(n=19)\end{array}$ & $\mathbf{p}$ \\
\hline Age (years) & $70.57 \pm 5.61$ & $68.06 \pm 7.47$ & $67.5 \pm 6.75$ & $67.21 \pm 7.68$ & 0.351 \\
\hline \multicolumn{6}{|l|}{ Gender n (\%) } \\
\hline Female & $0(0)$ & $2(6.3)$ & $1(10)$ & $0(0)$ & 0.302 \\
\hline Male & $26(100)$ & $30(93.7)$ & $9(90)$ & $19(100)$ & \\
\hline BMI $\left(\mathrm{kg} / \mathrm{m}^{2}\right)$ & $25.9 \pm 3.32$ & $25.91 \pm 3.39$ & $27.98 \pm 4.67$ & $25.02 \pm 5.62$ & 0.336 \\
\hline \multicolumn{6}{|l|}{ Smoking (\%) } \\
\hline Nonsmoker & $0(0)$ & $0(0)$ & $0(0)$ & $0(0)$ & 0.334 \\
\hline Ex-smoker & $14(53.8)$ & $24(75)$ & $7(70)$ & $14(73.7)$ & \\
\hline Active smoker & $12(46.2)$ & $8(25)$ & $3(30)$ & $5(26.3)$ & \\
\hline Smoking amount (packs/year) & $47(40-60)$ & $52.5(40-80)$ & $50(40-82.5)$ & $40(30-55)$ & 0.282 \\
\hline CAT & $4.23 \pm 2.32$ & $13.93 \pm 5.89$ & $6.9 \pm 1.66$ & $18.21 \pm 7.87$ & $<0.001^{*}$ \\
\hline $\mathrm{mMRC}$ & $1(0.75-1)$ & $2(2-2.75)$ & $1(1-2.25)$ & $3(2-3)$ & $<0.001^{* *}$ \\
\hline FVC\% & $87.23 \pm 19.21$ & $87.03 \pm 23.69$ & $71.06 \pm 11.44$ & $68.6 \pm 17.87$ & $0.003 \gamma$ \\
\hline FEV1\% & $71.54 \pm 19.14$ & $66.11 \pm 19.48$ & $51.6 \pm 11.96$ & $45.1 \pm 16.12$ & $<0.001 \tau$ \\
\hline FEV1/FVC & $65.06(52.07-68.21)$ & $59.93(52.2-65.72)$ & $55.51(50.12-65.8)$ & $46.14(38.4-56.4)$ & $0.002 \#$ \\
\hline Endocan & $376.88 \pm 72.21$ & $357.37 \pm 53.71$ & $357.6 \pm 45.5$ & $373.95 \pm 48.86$ & 0.554 \\
\hline ICAM-1 & $57.62 \pm 16.25$ & $57.61 \pm 15.67$ & $63.28 \pm 12.51$ & $53.49 \pm 13.39$ & 0.427 \\
\hline
\end{tabular}

* Significant differences were present between group $A$ and groups $B, C, D$, between group $B$ and groups $A$, $D$, between group $C$ and groups $A, B, D$.

**Significant differences were present between group $A$ and groups $B, C$, Detween group $B$ and group $D$, between group $C$ and group $D$.

$\gamma$ Significant differences were present between group $D$ and groups $A, B$.

$\tau$ Significant differences were present between group $A$ and groups $C, D$, between group $B$ and group $D$.

\# Significant differences were present between group $D$ and groups $A, B, C$.

BMI: body mass index, CAT: COPD assessment test, mMRC: Modified Medical British Research Council dyspnea questionnaire, FVC: forced vital capacity, \% pred.: percent predicted, FEV1: forced expiratory volume in 1 s., ICAM-1: Intercellular Adhesion Molecule-1.

( $p=0.878$ and $p=0.589$, respectively) (Table 3 ). When the patients were classified according to the GOLD classification, 26 patients were in Group A, 32 patients in Group B, ten patients in Group C, and 19 patients in Group D. The four groups were similar regarding age, gender, BMI, and smoking status. The highest CAT and mMRC scores were in Group D, followed by Groups B, C, and $A(p<0.001$ and $p<0.001$, respectively). The lowest pulmonary function parameter values were in Group D, followed by Groups C, B, and A
( $p=0.003, p<0.001$, and $p=0.002$, respectively). The endocan and sICAM-1 levels were similar in all four groups (Table 4). When the correlations of the endocan and SICAM-1 values with the functional and clinical parameters were investigated, it was found that endocan was negatively correlated with FVC\% and FEV1\% and positively correlated with CAT and mMRC scores and the amount of smoking. On the other hand, the only positive correlation of SICAM-1 was with the amount of smoking (Table 5). 


\section{DISCUSSION}

In our study, endothelial dysfunction and systemic inflammation were evaluated with serum endocan and ICAM-1 levels in COPD patients and the associations between comorbidities and these markers were investigated.

The associations of COPD with systemic inflammation and endothelial dysfunction have been shown with different markers in COPD-related studies (26-29). The number of studies conducted with endocan in COPD patients is few, and their results are contradictory. For example, in the study conducted by Kechagia et al., the endocan levels were reported to be similar in COPD patients encountering exacerbation and the control group ${ }^{(13)}$. However, the small number of cases in that study (32 COPD patients and 15 control cases) might have affected the results. In the same study, among the COPD patients in the stable group, the endocan levels were higher in patients encountering more exacerbations and hospitalizations than those who had fewer exacerbations. In their conclusion, the authors stated that endocan could predict patients who would encounter exacerbations. In their study with 55 stable COPD patients, 36 COPD cases with exacerbation, and 27 control cases, Dai et al. reported that the endocan levels of the COPD patients, either stable or undergoing exacerbations, were significantly higher when compared to their control group ${ }^{(14)}$. They found that the endocan levels of COPD patients with and without exacerbations were similar. Pihtili et al., in their study with 47 COPD patients and 41 control cases, reported that the endocan level of the COPD patient group was higher than the control group (15). In our study, consistent with Pihtili et al. and Dai et al., the endocan level of the COPD patient group was higher than the control group. The higher number of our sample cases than studies in the literature increases our study results' reliability.
In our study, when the COPD patients were grouped as those with and without comorbidities, the two groups were similar regarding the endocan and sICAM-1 levels, revealing that COPD is a disorder with endothelial dysfunction and systemic inflammation, independent of comorbidities. COPD patients with comorbidities were not included in the study conducted by Dai et al. ${ }^{(14)}$, whereas in the study of Pihtili et al., diabetes mellitus and hypertension were included as comorbidities, and COPD patients with other comorbidities were excluded ${ }^{(15)}$. However, COPD is a disorder with comorbidities in everyday life. In our study, COPD patients with all comorbidities were included in the study except for those with malignancy, those who had encountered an acute coronary syndrome or acute cerebrovascular disease, and those with symptoms and signs of acute infection. For this reason, we think that our study's COPD patient group reflects the actual COPD population better. Besides, we have not encountered any study evaluating COPD and its comorbidities with SICAM-1 in the literature. We think that our study is valuable also from this perspective.

In our study, the COPD subgroups were determined to be similar regarding the endocan and sICAM-1 levels, revealing that COPD is a disorder with endothelial dysfunction and systemic inflammation, independent of disease severity. Among studies evaluating the endocan level in COPD, the COPD groups were compared regarding the endocan level only in the study conducted by Pihtili et al ${ }^{(15)}$. In that study, endocan levels of the groups were similar to each other. However, since no patient was present in group $A$ in the study of Pihtili et al., it is difficult to draw a generalized conclusion regarding all COPD patients. Because there were patients in all COPD groups in our study, we think that our study's results are more reliable. We encountered no study comparing COPD groups regarding SICAM-1 level in the literature. We think that our study is also impor- 
tant in this respect.

There are few studies performed with the sICAM-1 level in COPD in the literature. Blidberg et al. reported that COPD patient groups with and without smoking had higher serum SICAM-1 levels than the control group (22). Noguera et al. determined in their study that the serum SICAM-1 level of their stable COPD group was lower when compared to healthy nonsmoker controls ${ }^{(23)}$. In a study conducted on rats, ICAM-1 expression in lung tissues of rats with COPD (determined immunohistochemically), and ICAM-1 mRNA levels (determined by PCR), were found to be increased ${ }^{(30)}$.

Different results are present regarding the relationship between the endocan level and functional/clinical parameters in the literature. For example, in the study conducted by Kechagia et al., no correlation was present between the endocan level and clinical parameters ${ }^{(13)}$, whereas Dai et al. reported that the endocan level was negatively correlated with FVC, FEV1, and FEV1/FVC ${ }^{(14)}$. In our study, we found that endocan level was negatively correlated with $\mathrm{FVC} \%$ and $\mathrm{FEV} 1 \%$, and positively correlated with CAT, MMRC, and amount of smoking, suggesting that endocan could predict airway obstruction severity. In our study, sICAM-1 level was not correlated with pulmonary function parameters and CAT and mMRC scores, whereas it was positively correlated only with the amount of smoking. Different results were obtained in studies investigating correlations between SICAM-1 level and pulmonary function in the literature. For example, in the study conducted by Walter et al., the serum SICAM-1 level was reported as negatively correlated with FEV1 (24); whereas no correlation was reported between the serum sICAM-1 level and pulmonary function in the study of Aaron et al ${ }^{(19)}$.

In the present study, we determined more active smokers in the group without comorbidity. Such active smokers should be encouraged to quit smoking by informing them with objective data about their risk regarding systemic inflammation and endothelial dysfunction similar to those who have comorbidities.

There are some limitations in our study. Firstly, the number of patients was small in the COPD subgroups. Secondly, the amount of smoking was less in the control groups. These situations may have affected the results.

In conclusion, systemic inflammation and endothelial dysfunction are present in COPD patients, independent of their comorbidities and disease severity and we think that endocan is a useful marker to predict severity of airway obstruction in these patients.

Ethics Committee Approval: Approval was obtained from the Non-Invasive Clinical Research Ethics Committee of Adnan Menderes University Faculty of Medicine (2018/1387).

Conflict of Interest: There is no conflict of interest. Funding: No financial support was received for the study.

Informed Consent: Has been taken.

\section{REFERENCES}

1. Global Strategy for the Diagnosis, Management and Prevention of COPD, Global Initiative for Chronic Obstructive Lung Disease (GOLD) 2017. Available from: http://goldcopd.org.

2. Okutan O, Ayten Ö. Kronik obstrüktif akciğer hastalığı ve komorbiditeler. Solunum 2012;14(3):182-3. https://doi.org/10.5505/solunum.2012.36024

3. Kechagia M, Papassotiriou I, Gourgoulianis KI. Endocan and the respiratory system: a review. Int J Chron Obstruct Pulmon Dis. 2016;11:3179-87. https://doi.org/10.2147/COPD.S1 18692

4. Arnson Y, Shoenfeld Y, Amital H. Effects of tobacco smoke on immunity inflammation and autoimmunity. J Autoimmun 2010;34:258-65. https://doi.org/10.1016/j.jaut.2009.12.003

5. Hillas G, Perlikos F, Tsiligianni I, Tzanakis N. Managing comorbidites in COPD. Int J Chron Obstruct Pulmon Dis 2015; 10:95-109.

https://doi.org/10.2147/COPD.S54473 
6. Dursunoğlu N, Köktürk N, Baha A, et al. Turkish Thoracic Society-COPD Comorbidity Group. Comorbities and their impact on chronic obstructive pulmonary disease. Tuberk Toraks 2016;64:292-301. https://doi.org/10.5578/tt.2245

7. Béchard D, Scherpereel A, Hammad H, et al. Human endothelial-cell specific molecule- 1 binds directly to the integrin CD11a/CD18 (LFA-1) and blocks binding to intercellular adhesion molecule-1. J Immunol 2001;167(6):3099-106.

https://doi.org/10.4049/jimmunol.167.6.3099

8. Mikkelsen ME, Shah CV, Scherpereel A, et al. Lower serum endocan levels are associated with the development of acute lung injury after major trauma. J Crit Care 2012;27(5):522. https://doi.org/10.1016/j.jcrc.2011.07.077

9. Tang L, Zhao Y, Wang D, et al. Endocan levels in peripheral blood predict outcomes of acute respiratory distress syndrome. Mediators Inflamm 2014;2014:625180. https://doi.org/10.1155/2014/625180

10. Grigoriu BD, Depontieu F, Scherpereel A, et al. Endocan expression and relationship with survival in human nonsmall cell lung cancer. Clin Cancer Res 2006;12(15):457582. https://doi.org/10.1158/1078-0432.CCR-06-0185

11. Kao SJ, Chuang CY, Tang $\mathrm{CH}$, et al. Plasma endothelial cell-specific molecule-1 (ESM-1) in management of community-acquired pneumonia. Clin Chem Lab Med. 2014;52(3):445-51. https://doi.org/10.1515/cclm-2013-0638

12. Güzel A, Duran L, Köksal N, et al. Evaluation of serum endothelial cell specific molecule-1 (endocan) levels as a biomarker in patients with pulmonary thromboembolism. Blood Coagul Fibrinolysis 2014;25(3):272-6. https://doi.org/10.1097/MBC.0000000000000071

13. Kechagia M, Michalakakou K, Griniouk K, et al. Serum endocan levels in patients with chronic obstructive pulmonary disease: a potential role in the evaluation of susceptibility to exacerbation. Clin Chem Lab Med. 2018;56(12):e295-e297. https://doi.org/10.1515/cclm-2018-0331

14. Dai L, He J, Chen J, et al. The association of elevated circulating endocan levels with lung function decline in COPD patients. Int J Chron Obstruct Pulmon Dis. 2018;13:3699-706. https://doi.org/10.2147/COPD.S175461

15. Pihtili A, Bingol Z, Kiyan E. Serum endocan levels in patients with stable COPD. Int J Chron Obstruct Pulmon Dis. 2018;13:3367-72.
https://doi.org/10.2147/COPD.S182731

16. Mukhopadhyay S, Malik P, Arora SK, Mukherjee TK. Intercellular adhesion molecule-1 as a drug target in asthma and rhinitis. Respirology 2014;19(4):508-13. https://doi.org/10.1111/resp.12285

17. Liao JK. Linking endothelial dysfunction with endothelial cell activation. J Clin Invest. 2013;123(2):540-1. https://doi.org/10.1172/JCl66843

18. Rahman A, Fazal F. Hug tightly and say goodbye: role of endothelial ICAM-1 in leukocyte transmigration. Antioxid Redox Signal. 2009; 11:823-39. https://doi.org/10.1089/ars.2008.2204

19. Aaron CP, Schwartz JE, Bielinski SJ, Hoffman, et al. Intercellular adhesion molecule 1 and progression of percent emphysema: The MESA Lung Study. Respir. Med. 2015;109:255-64.

https://doi.org/10.1016/j.rmed.2014.10.004

20. Kotteas EA, Boulas P, Gkiozos I, Tsagkouli S, Tsoukalas G, Syrigos KN. The intercellular cell adhesion molecule-1 (icam-1) in lung cancer: implications for disease progression and prognosis. Anticancer Res. 2014;34(9):466572.

21. Okuda R, Matsushima H, Aoshiba K, et al. Soluble intercellular adhesion molecule- 1 for stable and acute phases of idiopathic pulmonary fibrosis. Springerplus 2015;4:657.

https://doi.org/10.1186/s40064-015-1455-z

22. Blidberg K, Palmberg L, James A, et al. Adhesion molecules in subjects with COPD and healthy nonsmokers: a cross sectional parallel group study. Respir Res 2013;14: 47 https://doi.org/10.1186/1465-9921-14-47

23. Noguera A, Busquets $X$, Sauleda J, Villaverde JM, MacNee W, Agusti AG. Expression of adhesion molecules and $G$ proteins in circulating neutrophils in chronic obstructive pulmonary disease. Am J Respir Crit Care Med. 1998;158:1664-8. https://doi.org/10.1164/ajrccm.158.5.9712092

24. Walter RE, Wilk JB, Larson MG, et al. Systemic inflammation and COPD: the Framingham Heart Study. Chest 2008; 133:19-25.

https://doi.org/10.1378/chest.07-0058

25. Miller MR, Crapo R, Hankinson J, et al. General considerations for lung function testing. Eur Respir J 2005;26:15361. https://doi.org/10.1183/09031936.05.00034505

26. Donaldson GC, Seemungal TA, Patel IS, et al. Airway and systemic inflammation and decline in lung function in patients with COPD. Chest 2005;128(4):1995-2004. 
https://doi.org/10.1378/chest.128.4.1995

27. Agustí A, Faner R. Systemic inflammation and comorbidities in chronic obstructive pulmonary disease. Proc Am Thorac Soc 2012;9(2):43-6. https://doi.org/10.1513/pats.201108-050MS

28. Wanner A, Mendes ES. Airway endothelial dysfunction in asthma and chronic obstructive pulmonary disease: a challenge for future research. Am J Respir Crit Care Med. 2010;182(11):1344-51.

https://doi.org/10.1164/rccm.201001-0038PP
29. Yang Q, Underwood MJ, Hsin MK, Liu XC, He GW. Dysfunction of pulmonary vascular endothelium in chronic obstructive pulmonary disease: basic considerations for future drug development. Curr Drug Metab. 2008; 9(7):661-77. https://doi.org/10.2174/138920008785821684

30. Ji M, Wang Y, Li X, Qian Z. Up-regulation of ICAM$1 \mathrm{mRNA}$ and IL-1 $\beta$ mRNA in lung tissues of a rat model of COPD. Int J Clin Exp Med. 2015; 8(11):21956-63. 